\title{
Mapping of Regencies/City in Bali Province Based on Education Indicators
}

\author{
I.K.G.Sukarsa \\ Mathematics and Science Department, Faculty of Mathematics \& Science,Udayana University, \\ Jimbaran, Badung Regency,Bali 803611, Indonesia. \\ Telp/Fax : +62 (361)703137, E-mail : sukarsakomang@yahoo.com \\ G.K. Gandhiadi \\ Mathematics and Science Department, Faculty of Mathematics \& Science,Udayana University, \\ Jimbaran, Badung Regency,Bali 803611, Indonesia. \\ Telp/Fax : +62 (361)703137, E-mail : gandhiadigk@yahoo.com.
}

\begin{abstract}
Education Development is one of the important elements of Human Resource Development (HR). In order for education development to be carried out properly, one of the important things is to know how to map the development of education in an area (for example the regencies in this study) based on predetermined education indicators. Based on the map, it can be seen that the education indicator is dominant in an area. With this information, the direction of education development in each region can be designed according to regional conditions by increasing indicators that are relatively lacking and maintaining $a$ good indicator. This study aims to produce information in the form of education development maps in regencies/city in Bali Province based on education indicators so that they can be used as a reference for education development policies in each regencies. The resulting map will provide information on the condition of education indicators in a regencies. To get an overview of the map, Biplot Analysis is carried out on education indicator data. This analysis will provide a graph of the position of objects (regencies / city) and the relationships between variables (education indicators) simultaneously. The results of the analysis in graphical form with biplot shows that Gianyar Regency and Tabanan Regency are regencies that generally have close characteristics. This means that based on education indicators, the two regencies have similar indicators. The same thing is also seen in Karangasem and Bangli. While 5 (five) other regencies / city appear to have different indicator characteristics, the position of each regencies or city is far apart. Keywords: Biplot, Cluster Analysis, Educational Indicators
\end{abstract}

\section{Introduction}

Development of human resources (HR) is the main agenda of the Government of Indonesia as an effort to improve people's welfare. Efforts to improve the standard of living and welfare of the people of Indonesia are the main goals of national development. One of the efforts made to build human resources and educate the nation's life as one of the goals of national development is through education.Education is an absolute requirement to improve the quality of human resources to be reliable and competitive in the international arena. Education increasingly plays a role as one of the determinants of excellence in the face of the era of globalization and rapid technological development. One indicator used by the Central Statistics Agency to measure the quality of education in Indonesia is the Literacy Rate (LR). The results of SUSENAS (2005) show that the LR of Bali Province at the national level is 90.91\%. Bali Provincial BPS Data 2007 also shows that the Human Development Index of each regencies/city in Bali Province is on average lower than the National HDI.One way that 
can be taken by the city/regency government in Bali Province in improving the quality of education is to balance the condition of education variables by increasing the low variable score and maintaining a high score. Efforts to balance the condition of education variables will be effective if the relative position of the regencies/city is known, and the relationship of each variable with other variables can be known.

In the field of Statistics, especially in Multivariate Analysis, there are tools that can describe the relative position of regencies/city and the relationships between education variables. The right tool for this purpose is Biplot Analysis. Biplot analysis is an analysis that overlaps the description of the object position (regencies/city in this case) and an overview of variables (education variables) in one graph that can later be interpreted as object positions and at the same time the relationship between variables (correlation between variables). The objectives of this study are as follows:

1. To get a mapping of the position of /city in Bali Province based on the similarity of characteristics of the education variables studied;

2. To find out the education variables that need to be improved so that the development of education in a regencies/city in Bali Province can be more directed.

\section{Research Method}

Biplot analysis is a single graph display with low dimensions estimating data matrix elements through row and column configuration matrices (Gabriel, 2002). The interesting side of biplot is the fact that biplot can reduce high dimension data and its appearance is able to present objects that are observed together with variables that influence it simultaneously. Noting this, biplot is a concise, interesting and informative graphic demonstration technique. These dimensions are then arranged according to the diversity donations they have. To display a two-dimensional graph display with major diversity, the first two dimensions are chosen (Kroonenberg, 1997). This supports conditions where graphs with more than two dimensions are usually difficult to make, let alone interpret, so the biplot demonstration is generally displayed in two dimensions.

The term $b i$ on biplot is associated with simultaneous demonstrations between rows and columns of the matrix (Kroonenberg, 1997). Through this demonstration, it is expected to obtain object images, for example, the proximity between objects and variables, both about diversity and correlation, and the relationship between objects and variables. The technique used in Biplot Analysis is singular value decomposition.

The singular value decomposition technique is an approach technique that can find the best low dimensional space for high dimension data matrices. Through this technique, coordinates on several precise dimensions can be obtained. Therefore, the decomposition of singular values is the basis of the biplot demonstration.

\section{Singular Value Decomposition}

Suppose that $\mathrm{X}$ is an $n \times p$ matrix and the $\operatorname{rank}$ is $\mathrm{r}[r \leq \min \{n, p\}]$, then the decomposition of the singular value of the matrix $\mathrm{X}$ is (Watkins, 1991)

$$
X=U \Lambda V^{\prime}
$$

Where :

$U$ is the $n x n$ left singular vector matrix and the eigenvector of matrix $X X^{\prime}$; 
$V^{\prime}$ is the transpose of the matrix $\mathrm{V}$ which is the right singular vector matrix of $p x p$ size and is the eigenvector of $X^{\prime} X$;

$\Lambda$ is nxp diagonal matrix, $\Lambda=\operatorname{diag}\left(\sqrt{\lambda_{1}}, \sqrt{\lambda_{2}}, \ldots, \sqrt{\lambda_{p}}\right)$ with

$\lambda_{1} \geq \lambda_{2} \geq \cdots \geq \lambda_{r}>\lambda_{r+1}=\lambda_{r+2}=\cdots=\lambda_{p}=0$ (Lipkovisch dan Smith, 2002)

\section{Results And Discussion}

One component of the Human Development Index is education. According to the Central Bureau of Statistics in Indonesia, there are several education indicators including Literacy Rate (AMH), School Participation Rate (APS), Average School Length (RLTS) and School Graduation Rate (ATS). School Participation Rate (APS) in this study included elementary school level (APS SD), junior high school level (APS SMP), high school level (APS SMA). School Graduation Rate (ATS) included elementary school (ATS elementary school), junior high school (ATS junior high school), high school (ATS high school), diploma (ATS D1 D2 D3, while in Indonesia there are programs D1 to D3), Bachelor ( ATS DIV-S1).

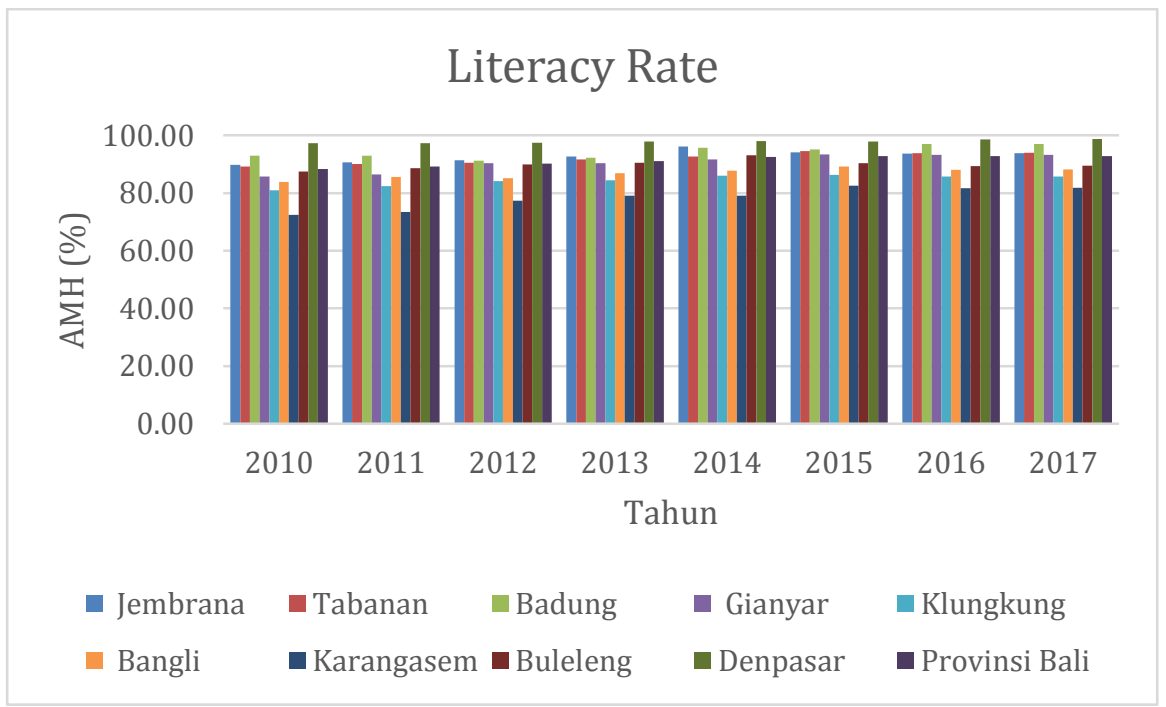

Figure 1 Literacy Rate by Regency/City in Bali

Literacy Rate (AMH) according to BPS (Central Agency on Statistics in Indonesia) is the proportion of the population aged 15 years and over who have the ability to read and write simple sentences in Latin letters, Arabic letters and other letters (such as Javanese letters, starch, etc.) for populations aged 15 years and over. Figure 1 shows that AMH in Karangasem Regency is the smallest among other regencies/city. In 2017 the percentage of AMH in Karangasem Regency was $89 \%$, which means that out of 100 residents, only 89 people had the ability to read and write. This percentage is still below the percentage of AMH in Bali Province (96.40\%). This is inversely proportional to Denpasar City, which has the highest percentage every year among other regencies. The percentage of AMH in Denpasar in 2017 is $99.70 \%$, this value is above the percentage of AMH in Bali Province. Some other regencies with above AMH percentage in Bali Province are Gianyar (97\%), Badung (99.10\%), Tabanan (97.60\%), and Jembrana (97.80\%). 


\section{Regency/City Classification in Bali Province with Biplot Analysis}

Biplot analysis will be representative if the diversity of data by the first two main components is more than 70\%. Research in 9 regencies/city in Bali Province with 10 research indicators as research variables provided information of $74.75 \%$. Because information can be explained $>70 \%$, it can be said that the biplot analysis provides sufficient information about the relationship between the 10 education indicators.

Grouping of objects (regencies/city), can be seen from the position of objects and variables in the plot. The closer the position between objects is, the grouping can be formed. In addition to looking at the object's position, the method of grouping can also be formed by making orthogonal projections from object coordinates to variable vectors. The closer the projection point of the object to the end of the vector, the greater the diversity that the vector contributes to the object. If the contribution of various variables to an object is relatively the same, then the objects are said to be 1 group. Figure 2 shows the regency/city grouping based on 10 education indicators

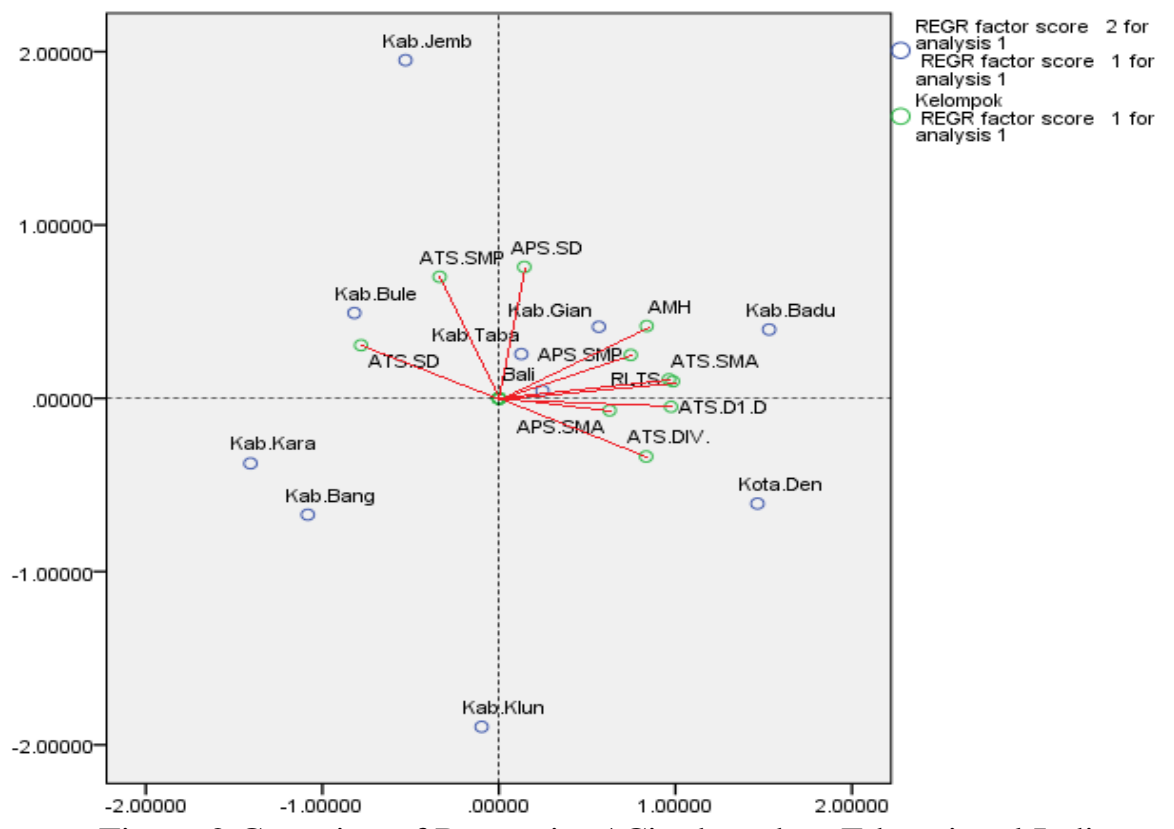

Figure 2 Grouping of Regencies / City based on Educational Indicators

The diversity of each education indicator in the biplot analysis can be seen from the length of the variable vectors formed, the longer the vector shows the greater level of diversity. The magnitude and correlation of education indicators are also shown in Figure 2. The greatest diversity is shown by the variable ATS SMA.This shows that the rate of graduating from high school spreads heterogeneously in regencies/city in Bali Province.

Literacy rates, high school participation rates, and primary school graduation rates have almost the same vector length, indicating the same relative diversity among the observed regencies/city. APS SD, APS SMP, RLTS, ATS SMP, and ATS (DI / DII / DIII, DIV, S1) have almost the same vector length, but the shortest size among other variables, this shows the variable with relatively homogeneous data between /city in Bali. 
The correlation between variables is indicated by the angle formed by two variable vectors.Taper angle shows a positive correlation, the blunt angle shows a negative correlation, while the right angle does not show a correlation between two variables. Cosine values are formed between two variables which state the correlation between variables is presented in Table 1.

Table 1 Correlation Between Educational Indicators

\begin{tabular}{|c|c|c|c|c|c|c|c|c|c|c|}
\hline & $\mathrm{X1}$ & $\mathrm{X} 2$ & $\mathbf{X 3}$ & $\mathrm{X} 4$ & X5 & X6 & $\mathrm{X} 7$ & X8 & X9 & X10 \\
\hline 1 & 1.000 & & & & & & & & & \\
\hline $\mathrm{X} 2$ & 0.253 & 1.000 & & & & & & & & \\
\hline $\mathrm{X} 3$ & 0.674 & 0.303 & 1.000 & & & & & & & \\
\hline $\mathrm{X} 4$ & 0.477 & 0.026 & 0.343 & 1.000 & & & & & & \\
\hline X5 & 0.916 & 0.136 & 0.697 & 0.478 & 1.000 & & & & & \\
\hline X6 & -0.380 & -0.087 & -0.408 & -0.475 & -0.682 & 1.000 & & & & \\
\hline X7 & 0.109 & 0.215 & -0.285 & -0.254 & -0.170 & 0.431 & 1.000 & & & \\
\hline $\mathrm{X} 8$ & 0.870 & 0.210 & 0.776 & 0.653 & 0.954 & -0.721 & -0.289 & 1.000 & & \\
\hline X9 & 0.797 & 0.106 & 0.667 & 0.638 & 0.926 & -0.780 & -0.337 & 0.937 & 1.000 & \\
\hline $\mathrm{X} 10$ & 0.621 & -0.218 & 0.438 & 0.309 & 0.857 & -0.779 & -0.357 & 0.754 & 0.831 & 1.000 \\
\hline \multirow{2}{*}{\multicolumn{11}{|c|}{$\begin{array}{l}\text { where: } \\
\mathrm{X} 1=\mathrm{AMH}\end{array}$}} \\
\hline & & & & & & & & & & \\
\hline \multicolumn{11}{|c|}{$\mathrm{X} 2=\mathrm{APS}$ SD } \\
\hline \multicolumn{11}{|c|}{ X3 = APS SMP } \\
\hline \multicolumn{11}{|c|}{ X4 = APS SMA } \\
\hline \multicolumn{11}{|c|}{ X5 = RTLS } \\
\hline \multicolumn{11}{|c|}{ X6 = ATS SD } \\
\hline \multicolumn{11}{|c|}{ X7 = ATS SMP } \\
\hline \multicolumn{11}{|c|}{ X8 = ATS SMA } \\
\hline \multicolumn{11}{|c|}{ X9 = ATS DI/DII/DIII } \\
\hline $\mathrm{X} 10$ & & & & & & & & & & \\
\hline
\end{tabular}

Furthermore, to find out the characteristics of the education indicators that characterize the groups formed can be seen in Figure 3.

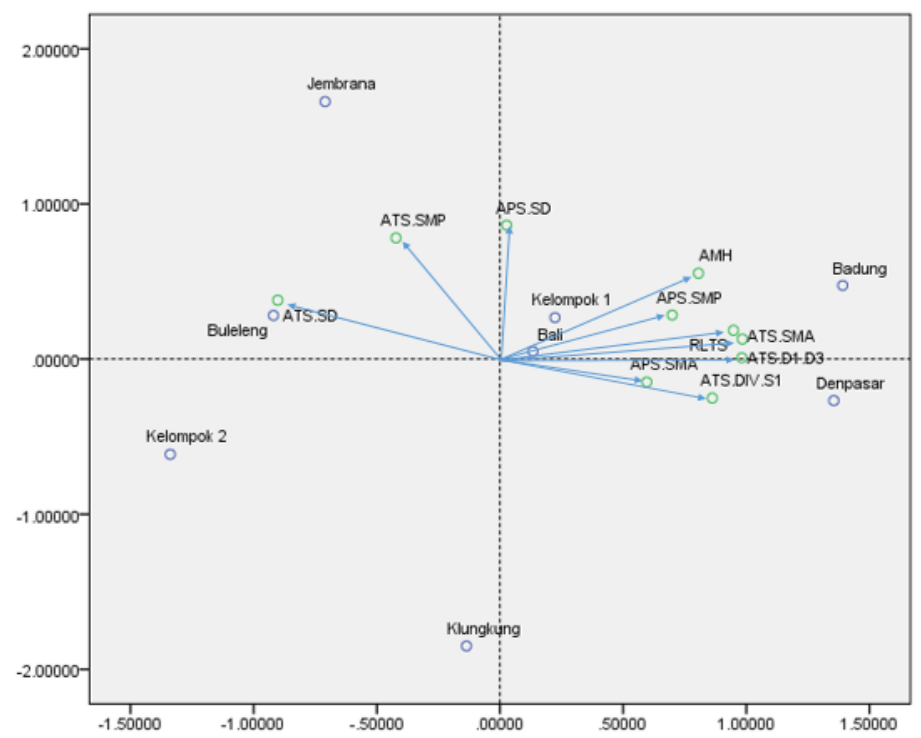

Figure 3 Biplot between regencies groups and education indicators 
Based on the proximity of the regency and city groups in Bali Province with the variables analyzed, group 1, namely Gianyar and Tabanan, were close to the AMH, APS (SD, SMP, SMA, DII, DII, DIV, and Bachelor) variables. This shows that the AMH and APS of Gianyar and Tabanan regencies are above average. Similarly, Denpasar and Badung have similar characteristics, but for the elementary school APS it is still below when compared to group 1. The position of Jembrana Regency is far from Group 1, Badung, and Denpasar is characterized by SMP ATS. Buleleng Regency is far from other regencies/city characterized by SD ATS. Group 2, which consists of Karangasem and Bangli , is far from Group 1, Badung and Denpasar, almost all indicators of education in group 2 are below the average. The closest is ATS SD, meaning that residents in Bangli and Karangasem still care education even though only up to elementary school. Similar to group 2, namely Klungkung regencies, its position is far from other regencies/city with AMH, ATS, RTLS, and APS still below average.

\section{Cluster Analysis}

Grouping results based on dendrogram into 4 groups marked with each coloras shown in Figure 4. This grouping is seen based on similarity values. For example, the dendrogram in group 1, which consists of Jembrana and Bangli regencies, has the same level of educational indicator characteristics. Gianyar and Tabanan based on dendrogram have similar characteristics from education indicators, where this group is similar in characteristics to the characteristics of Bali Province based on educational indicators. Badung and Denpasar regencies also show similar characteristics based on education indicators.

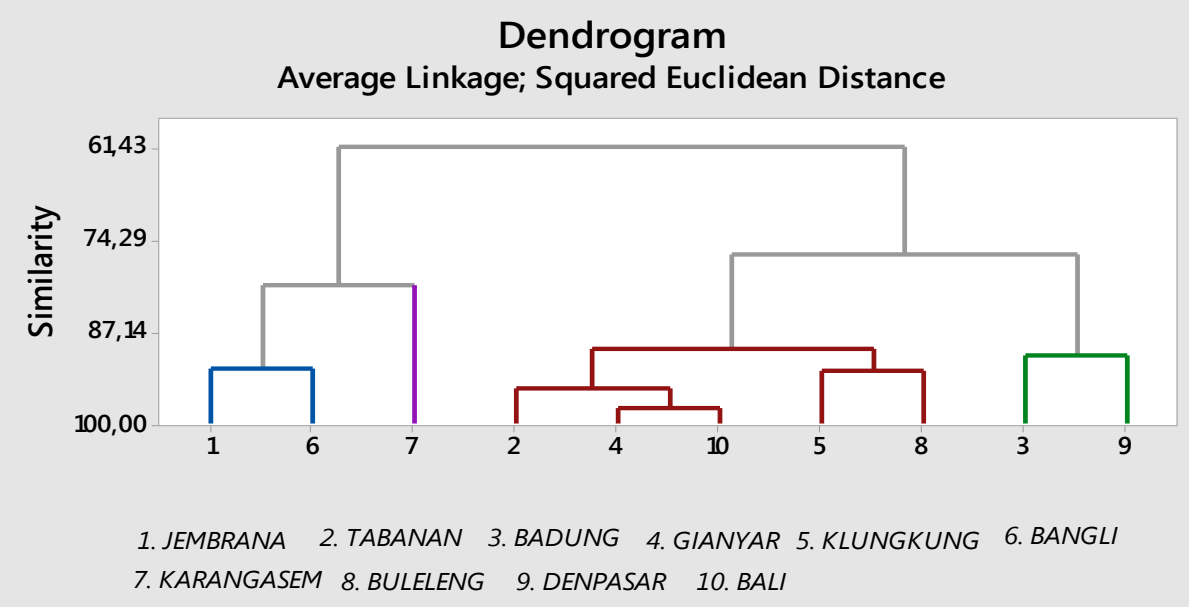

Figure 4 Results of the Regencies/City Education Indicator Dendrogram in Bali 2017

\section{Conclusions and Suggestions}

Research in 9 /city in Bali Province with 10 research indicators with biplot analysis obtained $74.75 \%$ of information that could be explained by biplot.25.25\% remaining minor errors that might occur due to reducing this dimension. Based on the proximity of the and city groups in Bali Province with the variables analyzed, group 1, namely Gianyar and 
Tabanan, was close to the AMH, APS (SD, SMP, SMA, DII, DII and DIV variables). This shows that AMH and APS of Gianyar and Tabanan regencies are above average. Likewise, Denpasar and Badung have similar characteristics, but for APS primary school is still below when compared to group 1. The position of Jembrana Regency is far from Group 1, Badung, and Denpasar is marked by ATS Middle School. Buleleng Regency is far from other regencies/city characterized by SD ATS. Group 2, which consists of Karangasem and Bangli , far from Group 1, Badung and Denpasar, almost all education indicators in group 2 are below average. The closest is ATS SD, meaning that residents in Bangli and Karangasem still care about education even though only to elementary school. Similar to group 2, namely Klungkung Regency, its position is far from other regencies/city and has social problems with AMH, ATS, RTLS, and APS indicators.

Grouping results based on dendrogram into 4 groups marked with each colour. This grouping is seen based on similarity values. Gianyar and Tabanan based on dendrogram have similar characteristics from education indicators, where this group is similar in characteristics to the characteristics of Bali Province based on educational indicators. Badung and Denpasar regencies also show similar characteristics based on education indicators.

\section{Suggestion}

In this study only discussed the Biplot method. Mapping of regencies/city in Bali Province based on education indicators can also be done by using other mapping techniques to find out the effectiveness of mapping performance graphically. Another technique is a combination of factor analysis and biplot analysis

\section{References}

BPS. 2003. Statistik Pendidikan 2003. Jakarta.

BPS Provinsi Bali. 2005. Statistik Pendidikan Hasil Sensus Sosial Ekonomi Nasional 2005. Denpasar.

BPS. 2006. Indikator Kesejahteraan Rakyat 2005. Jakarta.

Dillon, W.R and Matthew, G. 1984. Multivariate Analysis Methode and Application. John Wiley and Sons, Inc. Canada.

Gabriel, K.R. 2002. Goodness of Fit of Biplots and Correspondence Analysis. ProQuest Science Journals. pp. 423-436.

Kroonenberg, P.M. 1997. Introduction to Biplot for $G \times E$ Tables. http://threemode.leidenuniv.nl/document/biplot.pdf. Diakses Selasa, 10 Juli 2007.

Lipkovich, I and Eric P.S. 2002. Biplot and Singular Value Decomposition Macros for Excel@. http://www.jstatsoft.org/v07/i05/BIPLOT_paper_6_6_02.pdf. Diakses Selasa, 10 Juli 2007. 
I K.G. Sukarsa, G.K. Gandhiadi/Mapping of Regencies/City in Bali Province Base on Education Indicators

Morrison, D.F. 2005. Multivariate Statistical Methods. Fourth Edition. Thompson Brooks/Cole. Canada.

Mudyahardjo, R. 2002. Pengantar Pendidikan : Sebuah Studi Awal Tentang Dasar-dasar Pendidikan Pada Umumnya dan Pendidikan di Indonesia. PT. Raja Grafindo Persada. Jakarta.

Watkins, D.S. 1991. Fundamentals of Matrix Computations. John Wiley and Sons, Inc. Singapore. 